IJMS 16 (2), 21-38 (2009)

\title{
HUBUNGAN DINAMIK ANTARA INFLASI, KEMERUAPAN INFLASI DAN PERTUMBUHAN OUTPUT: BUKTI EMPIRIKAL DI MALAYSIA
}

\author{
ABU HASSAN SHAARI MOHD NOR \\ Fakulti Ekonomi dan Perniagaan \\ Universiti Kebangsaan Malaysia \\ TAN YAN LING \\ Fakulti Pengurusan Perniagaan \\ Universiti Teknologi MARA Johor
}

\begin{abstract}
ABSTRAK
Tujuan utama makalah ini adalah untuk mengkaji hubungan dinamik antara inflasi, kemeruapan inflasi dan pertumbuhan output bagi tempoh Januari 1980 hingga Disember 2004. Kemeruapan inflasi dianggarkan dengan menggunakan model varians bersyarat 'exponential generalized autoregressive conditional heteroskedasticity' (EGARCH) dan perubahan indek pengeluaran perindustrian (IPP) digunakan sebagai proksi kepada pertumbuhan output. Teknik autoregresi vector (VAR) digunakan untuk menguji kewujudan hubungan lead-lagged antara ketiga-tiga pemboleh ubah yang dikaji. Keputusan empirikal menunjukkan wujud hubungan penyebab antara kadar inflasi dan kemeruapan inflasi. Secara amnya, kadar inflasi yang tinggi akan meningkatkan kemeruapan inflasi, selaras dengan hipotesis pertama Friedman. Seterusnya kemeruapan inflasi yang tinggi akan mengurangkan kadar inflasi seperti yang dibahaskan oleh Holland. Tambahan pula, inflasi memberi kesan negatif terhadap pertumbuhan output Malaysia. Walau bagaimanapun tiada hubungan yang wujud antara kemeruapan inflasi dan pertumbuhan output. Keputusan daripada analisis luar sampel menggunakan teknik fungsi tindak balas teritlak (GIRF) dan penghuraian varians (VDC) adalah konsisten dengan keputusan daripada analisis VAR.
\end{abstract}

\section{ABSTRACT}

Purpose - The main purpose of this study was to analyse the dynamic relationship between inflation, inflation uncertainty and output growth in Malaysia for the period 1980 to 2004. 
Design/Methodology/Approach - The EGARCH model was used to estimate the inflation uncertainty and the Vector Autoregressive (VAR) technique, which includes the Granger causality test, was employed in the investigation of dynamic relationships between these variables.

Findings - There was significant evidence on the existence of one way positive relationships between inflation and inflation uncertainty in Malaysia. Further investigation showed that a high inflation level tends to have a negative effect on output growth. However, there was no significant evidence on the relationship between inflation uncertainty and output growth.

Originality/Value - This paper explores the time varying volatility of inflation in Malaysia and investigates the dynamic relationship between inflation, -inflation uncertainty, and output growth.

Keywords - EGARCH; inflation; inflation uncertainty; vector autoregressive.

\section{PENGENALAN}

Sejak kebelakangan ini, isu mengenai kadar inflasi, kemeruapan inflasi dan pertumbuhan output selalu dikaji oleh ahli-ahli ekonomi. Terdapat beberapa teori ekonomi yang menjelaskan hubungan antara inflasi dan pertumbuhan output seperti ekonomi Klasikal dalam teori sebelah penawaran, teori Keynes, teori Monetarism, teori Neoklasikal dan teori pertumbuhan endogen. Kebanyakan teori mendapati bahawa inflasi akan mengurangkan pertumbuhan output. Daripada sudut yang lain pula, Friedman (1977) dalam seminar 'Nobel Lecture' nya mengulas bahawa kadar inflasi yang tinggi akan meningkatkan kemeruapan -inflasi dan seterusnya memberi kesan negatif terhadap kecekapan aktiviti ekonomi. Dengan itu, dapat dirumuskan bahawa wujud dua hipotesis dalam Nobel Lecture Friedman iaitu inflasi kepada kemeruapan inflasi dan kemeruapan inflasi kepada pertumbuhan output. Ball (1992) mengkaji hipotesis pertama Friedman dengan menggunakan maklumat asimetri untuk menerangkan keadaan ini. Beliau mengatakan bahawa wujud dua jenis pembuat dasar dalam ekonomi iaitu pembuat dasar aktif dan pasif. Pembuat dasar aktif merupakan pembuat dasar yang berani menanggung kos disinflasi. Manakala pembuat dasar pasif pula tidak berani menanggung segala kos disinflasi. Semasa ekonomi berada dalam keadaan inflasi yang rendah, pembuat dasar sentiasa memastikan kadar inflasi dalam keadaan terkawal. Walau bagaimanapun, tempoh kadar inflasi yang tinggi akan meningkatkan 
kemeruapan inflasi kerana masyarakat tidak dapat meramal tindakan kerajaan, bank pusat dan pembuat dasar terhadap inflasi. Dengan itu, ketidakpastian mengenai inflasi masa depan meningkat. Manakala Cukierman dan Meltzer (1986) menunjukkan bahawa berlakunya proses inflasi yang bias semasa tempoh kemeruapan inflasi yang tinggi. Dalam keadaan ini, pembuat dasar menghadapi kesukaran menilai dasar yang akan dijalankan. Hal ini akan meningkatkan insentif bank pusat untuk bertindak secara oportunis. Oleh itu, jangkaan Cukierman dan Meltzer adalah peningkatan kemeruapan inflasi akan meningkatkan inflasi. Selain Cukierman dan Meltzer, Holland (1995) membahaskan bahawa kemeruapan inflasi yang tinggi akan mengurangkan kadar inflasi sekiranya bank pusat cuba meminimumkan kerugian kebajikan akibat daripada peningkatan kemeruapan inflasi berdasarkan hipotesis Fed penstabilan.

Di samping itu, majoriti kajian empirikal menunjukkan keputusan yang berbeza-beza. Berument dan Dincer (2005) menggunakan penganggaran secara serentak dan Grier dan Perry (1998) pula menggunakan penganggaran dua peringkat dalam mengkaji hubungan antara inflasi dan kemeruapan inflasi di negara-negara G7. Mereka mendapati bahawa semua negara G7 adalah menyokong hipotesis pertama Friedman. Tetapi, hasil kajian mereka adalah berbeza-beza dalam menyokong hipotesis Cukierman dan Meltzer dan hipotesis Holland. Kontonikas (2004) dan Fountas, Karanasos dan Karanassou (2000) menggunakan penganggaran secara serentak di negara UK turut menyokong hipotesis pertama Friedman. Sementara itu, Berument, Metin-Ozcan dan Neyapti (2001) dan Nas dan Perry (2000) masing-masing mengkaji hubungan antara inflasi dan kemeruapannya ke atas negara Turkey. Berument et al. (2001) mendapati bahawa kejutan positif inflasi memberi kesan yang lebih besar ke atas kemeruapan inflasi berbanding kejutan negatif inflasi. Nas dan Perry (2000) pula menggunakan penganggaran dua peringkat menunjukkan bahawa inflasi yang tinggi akan meningkatkan kemeruapan inflasi dalam semua sampel dan sub sampelnya. Sebaliknya hipotesis Cukierman dan Meltzer atau Holand adalah bergantung kepada sub sampel yang dikaji.

Tujuan utama kajian ini adalah untuk mengkaji hubungan dinamik antara inflasi, kemeruapan inflasi dan pertumbuhan output di Malaysia dengan menggunakan kaedah penganggaran dua peringkat. Kemeruapan inflasi dianggar berdasarkan permodelan exponential generalized autoregressive conditional heterocedastisity (EGARCH). Kemeruapan inflasi yang dianggar akan digunakan bersama dengan pembolehubah lain dalam ujian penyebab-Granger. Tambahan pula, 
penguraian varians (VDC) dan fungsi tindak balas teritlak (GIRF) akan digunakan bagi mengukuhkan hasil kajian yang didapati.

\section{DATA DAN METODOLOGI}

Inflasi adalah diproksikan berasaskan pembezaan pertama logarithma indeks harga pengguna (CPI) iaitu: $\pi_{t}=\log \left(C P I_{t} / C P I_{t-1}\right) * 100$. Manakala pertumbuhan output diproksikan berasaskan pembezaan pertama logaritma indeks pengeluaran perindustrian (IPP) iaitu: $y_{t}=\log \left(I P P_{t} / I P P_{t-1}\right) * 100$. Dalam mengkaji hubungan dinamik ini, data bulanan daripada Januari 1980 hingga Disember 2004 dengan tahun 2000 sebagai tahun asas digunakan. Kedua-dua jenis data ini diperoleh -melalui CD Rom International Financial Statistics, International Monetary Fund.

Berdasarkan Berument et al. (2001), model inflasi adalah terdiri daripada lat-lat inflasi dan pemboleh ubah-pemboleh ubah dami bulanan seperti merikut :-

$$
\pi_{t}=\theta_{0}+\sum_{i=1}^{p} \theta_{i} \pi_{t-i}+\sum_{i=1}^{12} \delta_{i} d_{t-i}+\varepsilon_{t}
$$

di mana

$\pi_{t-i}=$ kadar inflasi pada tempoh sebelumnya

$d_{t-i}=$ pembole uhbah dami bulanan $(i=1,2, \ldots \ldots, 12)$

Kesan ARCH diuji berdasarkan reja daripada model inflasi dalam persamaaan (1), menggunakan ujian Lagrange Multiplier (LM) seperti yang dicadangkan oleh Engle (1982). Ujian LM dijalankan dengan meregresikan reja kuasa dua daripada persamaan (1) terhadap konstan dan nilai-nilai latnya dengan kaedah penganggaran kuasa dua terkecil (OLS) seperti berikut :-

$$
\hat{\varepsilon}_{t}^{2}=\alpha_{0}+\sum_{i=1}^{q} \alpha_{i} \hat{\varepsilon}_{t-i}^{2}
$$

Hipotesis nol iaitu tiada kesan ARCH $\left(\mathrm{H}_{\mathrm{o}}: \alpha_{1}=\alpha_{2}=\ldots \ldots=\alpha_{q}=0\right)$ akan diuji melawan hipotesis alternatif iaitu ada kesan $\mathrm{ARCH}\left(\mathrm{H}_{1}\right.$ : sekurangkurangnya salah satu $\alpha_{i} \neq 0$ ). Sekiranya hipotesis nol ditolak, ini bermakna 
wujud kesan ARCH dalam persamaan min inflasi dan permodelan $\mathrm{ARCH}$ akan diteruskan bagi mendapatkan kemeruapan inflasi.

Sebelum permodelan autoregressive conditional heteroskedastisity $(\mathrm{ARCH})$ diperkenalkan oleh Engle (1982), ukuran sisihan piawai selalunya digunakan sebagai proksi kepada kemeruapan inflasi. Ukuran sisihan piawai hanya menunjukkan variasi kepada inflasi dan tidak dapat mencerminkan kemeruapan atau ketidakpastian inflasi. (Nas dan Perry, 2000). Model ARCH mencirikan bahawa varians ralat bersyarat adalah berbeza mengikut masa dan bukannya konstan. Justeru, model ARCH digunakan dalam menganggar persamaan min bersyarat dan persamaan varians bersyarat secara serentak seperti berikut:

Persamaan min bersyarat: $\operatorname{AR}(p)$

$$
\begin{aligned}
& \pi_{t}=\theta_{0}+\sum_{i=1}^{p} \theta_{i} \pi_{t-i}+\sum_{i=1}^{12} \delta_{i} d_{t-i}+\varepsilon_{t} \\
& \varepsilon_{t}=v_{t} \sigma_{t}
\end{aligned}
$$

di mana

$$
\varepsilon_{t} \sim \operatorname{NID}\left(0, \sigma_{t}^{2}\right) \text { dan } v_{\mathrm{t}} \sim \operatorname{iid}(0,1)
$$

Persamaan varians bersyarat: $\mathrm{ARCH}(q)$

$$
\begin{aligned}
& \sigma_{t}^{2}=\alpha_{0}+\alpha_{1} \varepsilon_{t-1}^{2}+\alpha_{2} \varepsilon_{t-2}^{2}+\ldots \ldots+\alpha_{q} \varepsilon_{t-q}^{2} \\
& \text { di mana } \\
& \alpha_{0}>0 \text { dan } \alpha_{i} \geq 0 \text { untuk } i>0
\end{aligned}
$$

Walau bagaimanapun, model ARCH memerlukan banyak parameter untuk menjadi model yang sesuai dalam penganggaran kemeruapan. Dengan itu, Bollerslev (1986) mencadangkan model alternatif lain iaitu generalized ARCH (GARCH) yang membenarkan varians bersyarat dicirikan sebagai proses purata bergerak autoregresif (ARMA). Kajian empirikal lepas selalu menyarankan bahawa pangkat yang pendek dalam model $\operatorname{GARCH}(p, q)$ adalah terbaik dalam penganggaran kemeruapan. Model $\operatorname{GARCH}(p, q)$ dapat ditulis dalam bentuk berikut:

$$
\sigma_{t}^{2}=\alpha_{0}+\sum_{i=1}^{q} \alpha_{i} \varepsilon^{2}{ }_{t-i}+\sum_{j=1}^{p} \beta_{j} \sigma_{t-j}^{2}
$$




$$
\begin{array}{ll}
\text { di mana } & \\
\alpha_{0}>0, \alpha_{i} \geq 0 & i=1,2, \ldots \ldots, q \\
\beta_{j} \geq 0 & j=1,2, \ldots \ldots, p \\
\alpha_{i}+\beta_{j}<1 &
\end{array}
$$

Secara ringkasnya, model GARCH(1,1) dapat ditunjukkan seperti berikut:

$$
\sigma_{t}^{2}=\alpha_{0}+\alpha_{1} \varepsilon^{2}{ }_{t-1}+\beta_{1} \sigma_{t-1}^{2}
$$

Sementara itu, Fountas et al. (2004) dan Berument et al. (2001) melaporkan bahawa model EGARCH adalah lebih baik berbanding -model ARCH dan GARCH berdasarkan tiga sebab. Pertama, model EGARCH membenarkan kesan asimetri yang positif dan negatif dalam kemeruapan inflasi. Kedua, permodelan EGARCH tidak mengenakan sebarang kekangan tidak negatif (non-negativity) ke atas parameter. (1)Manakala permodelan GARCH memerlukan semua parameter positif -dan jumlahnya kurang daripada satu. Ketiga, permodelan EGARCH dalam bentuk logaritma dapat mengelakkan masalah data pencilan (outlier) semasa penganggaran. Selain daripada ciri-ciri di atas, ciri-ciri lain boleh didapati dalam kajian Nelson (1991). Model EGARCH(1,1) ditulis dalam bentuk berikut:

$$
\log \sigma_{t}^{2}=\alpha_{0}+\gamma_{1}\left|\varepsilon_{t-1} / \sigma_{t-1}\right|+\alpha_{1}\left(\varepsilon_{t-1} / \sigma_{t-1}\right)+\beta_{1} \log \sigma_{t-1}^{2}
$$

Saiz parameter $\beta_{1}$ yang besar menunjukkan bahawa kemeruapan inflasi adalah berterusan meningkat. Manakala nilai parameter $\alpha_{1}>0$ dan signifikan menunjukkan kejutan positif mempunyai kesan yang -lebih besar ke atas kemeruapan inflasi berbanding dengan kejutan negatif. Pemilihan model EGARCH yang terbaik adalah berdasarkan ciri-ciri kriteria informasi seperti Akaike Information Criterion (AIC) dan Schwarz Criterion (SC). Contohnya, model A adalah dikatakan lebih baik daripada model B jika nilai AIC dan SC untuk model A adalah lebih kecil berbanding model B. Selain kriteria informasi, ujian diagnostik iaitu statistik- $Q$ Ljung Box untuk reja terpiawai iaitu $\hat{s}_{t}=\hat{\varepsilon}_{t} / \hat{\sigma}_{t}$ diuji ke atas persamaan min dan reja terpiawai kuasa dua iaitu $\hat{s}_{t}^{2}$ diuji ke atas persamaan varians bersyarat. Sesuatu model dikatakan model yang terbaik di mana siri $\hat{s}_{t}$ dan $\hat{s}_{t}^{2}$ masing-masing bebas daripada masalah siri kolerasi dan heteroskidastisiti bersyarat.

Plot kuartil-kuartil (QQ) digunakan dalam menentukan kenormalan taburan reja terpiawai daripada model EGARCH. Plot QQ akan berada di 
sepanjang garis lurus sekiranya taburan reja terpiawai adalah bertaburan normal. Taburan reja terpiawai yang berbentuk cekung adalah pencong ke kanan. Manakala bagi taburan yang berbentuk cembung pula adalah pencong ke kiri.

Untuk tujuan mengkaji hubungan antara inflasi dan kemeruapannya, kajian ini akan menggunakan penganggaran dua peringkat. Di peringkat pertama kemeruapan inflasi dianggarkan menggunakan persamaan (8). Peringkat kedua pula melibatkan penggunaan model VAR seperti diberikan dalam persamaan (9)-(11). Fountas et al. (2004) melaporkan bahawa penganggaran dua peringkat adalah lebih baik berbanding penganggaran secara serentak dengan tiga sebab, iaitu (a) Penganggaran dua peringkat dapat menguji kesan lat yang lebih panjang antara pemboleh ubah yang dikaji. (b) Penganggaran secara serentak berpotensi menghasilkan varians yang negatif. (c) Ujian penyebabGranger dapat meminimumkan bilangan parameter yang dianggar. Di samping itu, mereka turut mendapati bahawa penganggaran secara serentak tidak dapat mengesan kesan kemeruapan ke atas kadar inflasi dalam kebanyakan negara yang dikaji. Ini disebabkan sekiranya wujud kesan kemeruapan inflasi ke atas inflasi melalui sebarang perubahan dasar penstabilan seperti dasar kewangan, ianya akan mengambil masa yang panjang untuk dilaksanakan, bukannya pada jangka masa pendek atau secara serta-merta. Dengan itu, untuk mendapat keputusan yang lebih memuaskan, penganggaran dua peringkat akan digunakan. Penganggaran dua peringkat merupakan penganggaran di mana varians bersyarat dianggar terlebih dahulu dengan menggunakan model EGARCH dan kemudiannya digunakan untuk menjalankan ujian penyebab-Granger. Hubungan antara inflasi, kemeruapan inflasi dan pertumbuhan output dapat ditunjukkan dengan menggunakan model autoregresi vektor (VAR) seperti berikut :-

$$
\begin{aligned}
& I N F_{t}=\alpha_{0}+\sum_{i=1}^{n} \gamma_{i} I N F_{t-i}+\sum_{i=1}^{n} \lambda_{i} \operatorname{INFUNC}_{t-i}+\sum_{i=1}^{n} \theta_{i} Y_{t-i}+v_{1 t} \\
& I_{N F U N C_{t}}=\alpha_{0}+\sum_{i=1}^{n} \gamma_{i} I N F_{t-i}+\sum_{i=1}^{n} \lambda_{i} I_{N F U N C_{t-i}}+\sum_{i=1}^{n} \theta_{i} Y_{t-i}+v_{2 t} \\
& Y_{t}=\alpha_{0}+\sum_{i=1}^{n} \gamma_{i} I N F_{t-i}+\sum_{i=1}^{n} \lambda_{i} I_{N F U N C_{t-i}}+\sum_{i=1}^{n} \theta_{i} Y_{t-i}+v_{3 t}
\end{aligned}
$$


di mana

INFUNC $_{t} \quad=$ kemeruapan inflasi

$I N F_{t} \quad=$ kadar inflasi

$Y_{t} \quad=$ kadar pertumbuhan output

Hipotesis nol iaitu inflasi bukan penyebab-Granger kemeruapan inflasi $\left(\mathrm{H}_{\mathrm{o}}: \gamma_{1}=\gamma_{2}=\ldots \ldots=\gamma_{i}=0\right)$ diuji bersama dengan hipotesis alternatif iaitu inflasi penyebab-Granger kemeruapan inflasi $\left(\mathrm{H}_{1}\right.$ :sekurang-kurangnya salah satu $\gamma_{i} \neq 0$ ) pada lat 4, 8 dan 12 . Sekiranya hipotesis nol ditolak, ini bermakna inflasi adalah penyebab-Granger kepada kemeruapan inflasi. Selanjutnya ujian ini akan diteruskan dengan menguji hubungan penyebab antara pemboleh ubah yang lain.

-Ujian penyebab-Granger merupakan ujian yang hanya dapat menjelaskan hubungan antara pemboleh ubah dalam sampel. Ianya tidak membekalkan ciri-ciri dinamik dalam sistem bagi data di luar sampel dan tidak dapat mengukur kekuatan relatif atau darjah keeksogenan antara pemboleh ubah. Kaedah penghuraian varians (VDC) yang disebutkan -sebagai ujian penyebab luar sampel mengukur perubahan perkadaran sesuatu pemboleh ubah akibat daripada perubahan kejutan dirinya dan - perubahan kejutan pemboleh ubah lain dalam sistem VAR. Sesuatu pemboleh ubah dikatakan endogen (eksogen) sekiranya pemboleh ubah lain dapat menerangkan peratusan variasi dirinya dengan banyak (tidak dapat menerangkan variasinya).

Fungsi tindak balas (IRF) digunakan untuk mengkaji kesan suatu kejutan atau inovasi daripada sesuatu pemboleh ubah ke atas pemboleh ubah yang lain dalam model VAR. Teknik IRF menerima banyak kritikan di mana keputusannya sensitif terhadap susunan pemboleh ubah dalam -VAR. Dengan itu, Pesaran dan Shin (1998) mencadangkan fungsi tindak balas teritlak digunakan kerana ianya tidak sensitif terhadap susunan pemboleh ubah dalam VAR.

\section{KEPUTUSAN}

Jadual1 menunjukkan ujian kepegunan kadar inflasi, kadar pertumbuhan output dan kemeruapan inflasi dengan menggunakan ujian Augmented Dickey-Fuller (ADF) dan ujian Phillips-Perron (PP). Didapati bahawa setiap siri adalah menolak hipotesis nol iaitu tidak pegun. Hal ini dapat ditunjukkan dengan nilai statistik ujian adalah lebih besar daripada nilai kritikal Mac-Kinnon dan signifikan pada aras keertian 0.01, 0.05 dan 0.10 . 


\section{Ujian Kepegunan}

\begin{tabular}{lcccccc}
\hline & \multicolumn{2}{c}{ Kadar Inflasi } & \multicolumn{2}{c}{$\begin{array}{c}\text { Kadar Pertumbuhan } \\
\text { Output }\end{array}$} & \multicolumn{2}{c}{$\begin{array}{c}\text { Kemeruapan } \\
\text { Inflasi }\end{array}$} \\
\cline { 2 - 7 } Ujian Kepegunan & ADF & PP & ADF & PP & ADF & PP \\
\hline Statistik Ujian & -4.9819 & -13.884 & -14.8716 & -28.3605 & -7.2997 & -11.197 \\
Nilai Kritikal : 1\% & -3.9897 & -3.9892 & -3.9893 & -3.9892 & -3.9905 & -3.9898 \\
Nilai Kritikal : 5\% & -3.4252 & -3.425 & -3.4250 & -3.425 & -3.4256 & -3.4253 \\
Nilai Kritikal : 10\% & -3.1357 & -3.1356 & -3.1356 & -3.1356 & -3.136 & -3.1358 \\
AIC & 0.8448 & 0.8646 & 6.4519 & 6.4433 & -2.6005 & -2.5143 \\
SC & 0.9453 & 0.9018 & 6.5016 & 6.4805 & -2.4855 & -2.4765 \\
Lat & 5 & 5 & 1 & 1 & 6 & 6 \\
\hline
\end{tabular}

Nota.

(a) Nilai konstan dan tren linear masa adalah dimasukkan dalam ujian ADF dan ujian PP.

(b) $\mathrm{H}_{\mathrm{o}}$ siri $x_{t}$ adalah tidak pegun bertentangan dengan $\mathrm{H}_{1}$ siri $x_{t}$ adalah pegun.

(c) Pemilihan panjang lat optima bagi ujian ADF adalah berdasarkan kriteria informasi manakala ujian PP pula dilakukan dengan lat disetkan terpangkas seperti yang dinyatakan dalam Jadual 1.

Jadual 2 menunjukkan analisis statistik deskriptif bagi kadar inflasi dan kadar pertumbuhan output di Malayisa. Kedua-dua taburan siri masa cenderung mempunyai kurtosis yang lebih tinggi berbentuk leptokurtic dan pencong ke kanan. Manakala ujian Jarque-Bera menunjukkan kadar inflasi dan kadar pertumbuhan output adalah signifikan pada aras keertian 0.01 yang dikatakan bertaburan tidak normal.

Jadual 2

Analisis Statistik Deskriptif

\begin{tabular}{lcc}
\hline Statistik Deskriptif & Kadar Inflasi & Kadar Pertumbuhan Output \\
\hline Min & 0.2535 & 0.6913 \\
Median & 0.1957 & 0.4609 \\
Maksimum & 1.8617 & 39.9170 \\
Minimum & -1.5147 & -25.1476 \\
Sisihan Piawai & 0.3833 & 6.7718 \\
Kepencongan & 0.4768 & 0.6301 \\
Kurtosis & 5.8787 & 7.1050 \\
Jarque-Bera & 114.5747 & 229.7224 \\
Nilai- $p$ & $0.0000^{* * *}$ & $0.0000^{* * *}$ \\
Saiz Sample & 299 & 299 \\
\hline
\end{tabular}

Nota. ${ }^{* * *}$ menunjukkan signifikan pada aras keertian 0.01 . 
Jadual 3 menunjukkan keputusan penganggaran OLS yang dibentuk berdasarkan model autoregresif (AR) dan pembolehubah dami bulanan. Penganggaran ini dijalankan berdasarkan teknik Box-Jenkins yang menunjukkan bahawa model ini merupakan model terbaik dari segi kriteria informasi. Statistik- $Q$ Ljung Box untuk reja memberikan nilainilai $Q(6)=5.1214(0.2750)$ dan $Q(12)=9.3560(0.4990)$ dengan nilai $-p$ dalam kurungan menunjukkan bahawa tiada masalah autokolerasi. Manakala statistik-Q Ljung Box untuk reja kuasa dua pula menunjukkan wujud heteroskidastisiti di mana $Q^{2}(6)=32.0860(0.0000)$ dan $Q^{2}(12)=34.1220$ (0.0000). Dengan itu, dapat dirumuskan bahawa model inflasi dalam persamaan (1) bebas daripada masalah autokolerasi, tetapi masih terikat dengan masalah heteroskidastisiti.

\section{Jadual 3}

Keputusan Penganggaran OLS

\begin{tabular}{lccc}
\hline & Pemboleh Ubah & Pekali & Nilai- $p$ \\
\hline Konstan & $\theta_{0}$ & $0.2499^{* * *}$ & 0.0000 \\
$d_{2}$ & $\delta_{2}$ & $0.1768^{* *}$ & 0.0174 \\
$d_{3}$ & $\delta_{3}$ & $-0.2118^{* * *}$ & 0.0039 \\
$\pi_{t-1}$ & $\theta_{1}$ & $0.2120^{* * *}$ & 0.0003 \\
$\pi_{t-6}$ & $\theta_{6}$ & $0.1876^{* * *}$ & 0.0009 \\
AIC & & & \\
SC & & 0.7783 & \\
Log LL & & 0.8411 & \\
$\mathrm{Q}(6)$ & & -109.0187 & \\
$\mathrm{Q}(12)$ & & 5.1214 & 0.2750 \\
$\mathrm{Q}^{2}(6)$ & & 9.3560 & 0.4990 \\
$\mathrm{Q}^{2}(12)$ & & $32.0860^{* * *}$ & 0.0000 \\
\hline
\end{tabular}

Nota. ${ }^{* * *}{ }^{* *}$ mewakili signifikan pada aras keertian 0.01 dan 0.05 .

Keputusan dalam Jadual 4 menunjukkan bahawa model AR(1,6)EGARCH $(1,1)$ adalah lebih sesuai mencirikan kemeruapan inflasi di Malaysia. Semua pekali adalah signifikan pada aras keertian 0.01, 0.05 dan 0.10. Kesan asimetri seperti yang ditunjukkan oleh pekali $\alpha_{1}$ adalah positif dan signifikan pada aras keertian 0.05. Hal ini bermakna wujud kesan asimetri dalam kemeruapan inflasi di Malaysia di mana kejutan positif inflasi akan menyebabkan kemeruapan inflasi meningkat lebih banyak berbanding dengan kejutan negatif inflasi. Hal ini adalah berbeza dengan analisis kewangan di mana kejutan negatif selalunya 
meningkatkan kemeruapan lebih banyak berbanding dengan kejutan positif. Fountas et al. (2004) dan Berument et al. (2001) masing-masing melaporkan bahawa wujud kesan asimetri di mana tempoh kejutan inflasi yang positif diikuti dengan tempoh kemeruapan inflasi yang tinggi. Selain itu, saiz pekali $\beta_{1}$ menggambarkan kemeruapan inflasi akan berterusan meningkat. Tambahan pula, statistik- $Q$ LjungBox untuk reja terpiawai $\hat{s}_{t}$ menunjukkan $Q(6)=5.1910(0.2680)$ dan $Q(12)=15.5280$ (0.1140) dengan nilai- $p$ dalam kurungan menunjukkan bahawa tiada auto kolerasi dalam reja terpiawai bagi persamaan min. Manakala statistik- $Q$ Ljung-Box untuk reja terpiawai kuasa dua $\hat{s}_{t}^{2}$ pula dengan $\mathrm{Q}^{2}(6)=2.4359(0.6560)$ dan $\mathrm{Q}^{2}(12)=5.2868$ (0.8710) menunjukkan tiada heteroskidastisiti bersyarat dalam reja terpiawai bagi persamaan varians bersyarat. Di samping itu, taburan reja terpiawai daripada model AR(1,6)-EGARCH $(1,1)$ adalah berada di sepanjang garis lurus walaupun terdapat nilai ekstrim di kedua-dua hujung plot QQ (sila lihat Appendiks). Dengan itu, dapat disimpulkan bahawa model AR(1,6)EGARCH $(1,1)$ telah melepasi semua ujian diagnostik yang jalankan dan merupakan model yang sesuai dalam analisis kemeruapan kadar inflasi di Malaysia.

Jadual 4

Analisis Kemeruapan Inflasi: Model AR(1,6)-EGARCH(1,1)

\begin{tabular}{lccc}
\hline \multicolumn{1}{c}{ Pemboleh Ubah } & & Pekali & Nilai- $p$ \\
\hline Konstan & $\theta_{0}$ & $0.2335^{* * *}$ & 0.0000 \\
$d_{2}$ & $\delta_{2}$ & $0.1563^{* *}$ & 0.0103 \\
$d_{3}$ & $\delta_{3}$ & $-0.1623^{* *}$ & 0.0130 \\
$\pi_{t-1}$ & $\theta_{6}$ & $0.1539^{* *}$ & 0.0281 \\
$\pi_{t-6}$ & $\theta_{1}$ & $0.1807^{* * *}$ & 0.0001 \\
Konstan & & & \\
l $\varepsilon_{\mathrm{t}-1} / \sigma_{t-1} \mid$ & $\alpha_{0}$ & $-1.2687^{* *}$ & 0.0369 \\
$\varepsilon_{\mathrm{t}-1} / \sigma_{t-1}$ & $0.3104^{*}$ & 0.0580 \\
$\log \sigma^{2}{ }_{t-1}$ & $\gamma_{1}$ & $0.2262^{* *}$ & 0.0452 \\
$\mathrm{AIC}$ & $\alpha_{1}$ & $0.5356^{* *}$ & 0.0438 \\
$\mathrm{SC}$ & $\beta_{1}$ & 0.6912 & \\
$\mathrm{Log} \mathrm{LL}$ & & 0.8042 & \\
$\mathrm{Q}(6)$ & & -92.2576 & 0.2680 \\
$\mathrm{Q}(12)$ & & 5.1910 & 0.1140 \\
$\mathrm{Q}^{2}(6)$ & & 15.5280 & 0.6560 \\
$\mathrm{Q}^{2}(12)$ & & 2.4359 & 0.8710 \\
\hline
\end{tabular}

Nota. ${ }^{* * *}, * *$ dan $*$ menunjukkan signifikan pada aras keertian $0.01,0.05$ dan 0.10 . 
Hubungan antara inflasi, kemeruapan inflasi dan pertumbuhan output dapat ditunjukkan melalui analisis ujian penyebab-Granger (Jadual 5). Dalam kajian ini, lat 4, 8 dan 12 digunakan untuk menguji hubungan penyebab Granger antara ketiga-tiga pembolehubah yang dikaji. Hasil kajian mendapati wujud hubungan negatif antara inflasi dan pertumbuhan output yang signifikan pada aras keertian 0.05 (lat 4 dan 8). Selain itu, inflasi yang tinggi akan meningkatkan kemeruapan inflasi dan signifikan pada aras keertian 0.01 pada semua lat, selaras dengan hipotesis pertama Friedman. Manakala kemeruapan inflasi yang tinggi akan menurunkan kadar inflasi seperti yang dibahaskan oleh Holland yang berkonsepkan motif penstabilan harga. Dari sudut yang lain pula, hipotetsis kedua Friedman iaitu kemeruapan inflasi akan mengurangkan kecekapan ekonomi atau pertumbuhan output adalah tidak signifikan

-pada semua lat. Ini bererti wujud hubungan dua hala antara inflasi dan kemeruapan inflasi di negara Malaysia, tetapi tiada hubungan wujud antara kemeruapan inflasi dan pertumbuhan output.

Jadual 5

-

Ujian Penyebab-Granger

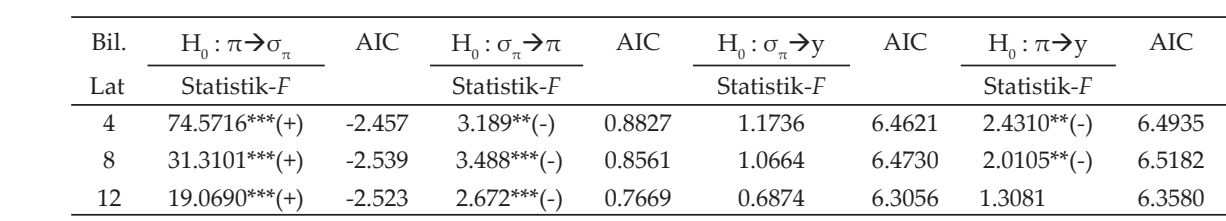

Nota.

: ****** dan * menunjukkan signifikan pada aras keertian 0.01, 0.05 .

$: \pi \rightarrow \sigma_{\pi}:$ Inflasi bukan penyebab-Granger kemeruapan inflasi.

$: \sigma_{\pi} \rightarrow \pi:$ Kemeruapan inflasi bukan penyebab-Granger inflasi.

$: \sigma_{\pi} \rightarrow \mathrm{y}:$ Kemeruapan inflasi bukan penyebab-Granger pertumbuhan output.

$: \pi \rightarrow \mathrm{y}:$ Inflasi bukan penyebab-Granger pertumbuhan output.

Berdasarkan Jadual 6, jelas menunjukkan bahawa pertumbuhan output dan inflasi di Malaysia cenderung merupakan pembolehubah eksogen dengan masing-masing 87.3 dan 82.50 peratus daripada varians ramalan diterangkan oleh kejutan dirinya selepas bulan ke-24. Manakala varians ramalan kemeruapan inflasi diterangkan oleh kejutan dirinya sebanyak 47.72 peratus selepas bulan ke-24. Selain itu, pemeriksaan secara melintang menunjukkan bahawa inflasi hanya diterangkan oleh kemeruapan inflasi sebanyak 10.34 peratus. Manakala, kemeruapan inflasi dapat diterangkan oleh inflasi sebanyak 46.65 peratus selepas bulan ke-24. Sementara itu, pertumbuhan output hanya dapat diterangkan oleh inflasi dan kemeruapan inflasi masing-masing sebanyak 8.53 peratus dan 4.13 peratus. Dengan itu, keputusan analisis penghuraian varians 
menunjukkan keeksogenan pembolehubah inflasi dalam menerangkan kemeruapan inflasi. Inflasi secara relatifnya menerangkan pertumbuhan output lebih banyak berbanding kemeruapan inflasi.

Jadual 6

Analisis Penghuraian Varians

\begin{tabular}{|c|c|c|c|c|}
\hline \multirow{3}{*}{$\begin{array}{c}\text { Varians Relatif } \\
\text { dalam }\end{array}$} & \multirow[b]{3}{*}{$\mathrm{t}$} & \multicolumn{3}{|c|}{ Peratusan varians ramalan diterangkan oleh kejutan dalam } \\
\hline & & & Kemeruapan & Pertumbuhan \\
\hline & & Inflasi & Inflasi & Output \\
\hline \multirow[t]{9}{*}{ Inflasi } & 1 & 100.00 & 0.00 & 0.00 \\
\hline & 2 & 93.07 & 5.93 & 1.00 \\
\hline & 3 & 92.49 & 6.37 & 1.15 \\
\hline & 4 & 92.04 & 6.34 & 1.62 \\
\hline & 5 & 89.87 & 7.87 & 2.26 \\
\hline & 6 & 89.69 & 7.85 & 2.45 \\
\hline & 12 & 85.04 & 10.37 & 4.59 \\
\hline & 24 & 82.50 & 10.34 & 7.17 \\
\hline & 36 & 81.96 & 10.37 & 7.67 \\
\hline \multirow{9}{*}{$\begin{array}{l}\text { Kemeruapan } \\
\text { Inflasi }\end{array}$} & 1 & 2.23 & 97.77 & 0.00 \\
\hline & 2 & 46.16 & 52.60 & 1.23 \\
\hline & 3 & 49.37 & 49.07 & 1.56 \\
\hline & 4 & 49.65 & 48.76 & 1.59 \\
\hline & 5 & 49.51 & 48.84 & 1.64 \\
\hline & 6 & 49.10 & 49.06 & 1.84 \\
\hline & 12 & 47.19 & 49.18 & 3.64 \\
\hline & 24 & 46.65 & 47.72 & 5.63 \\
\hline & 36 & 46.60 & 47.45 & 5.95 \\
\hline Pertumbuhan & 1 & 1.64 & 0.45 & 97.90 \\
\hline \multirow[t]{8}{*}{ Output } & 2 & 1.43 & 1.00 & 97.57 \\
\hline & 3 & 1.44 & 1.22 & 97.34 \\
\hline & 4 & 1.70 & 1.21 & 97.08 \\
\hline & 5 & 1.70 & 1.21 & 97.10 \\
\hline & 6 & 2.58 & 1.42 & 96.01 \\
\hline & 12 & 7.64 & 3.59 & 88.77 \\
\hline & 24 & 8.53 & 4.13 & 87.34 \\
\hline & 36 & 8.62 & 4.23 & 87.15 \\
\hline
\end{tabular}

Rajah 1 terdiri daripada fungsi tindak balas teritlak (GIRF) suatu pemboleh ubah hasil daripada kejutan satu sisihan piawai pemboleh ubah yang lain. Kejutan daripada inflasi merangsang tindak balas serta merta kemeruapan inflasi dan rangsangan ini bersifat sementara. Tindak balas ini meliar untuk jangka masa yang pendek iaitu kira-kira 5 bulan dan kembali stabil selepas itu.

Tindak balas inflasi hasil kejutan daripada kemeruapan inflasi tidak memberi kesan yang merangsangkan pergerakan inflasi sehingga 
tempoh 12 bulan. Dari segi analisis tindak balas pertumbuhan output pula, kejutan daripada kedua-dua pemboleh ubah iaitu kemeruapan inflasi dan inflasi juga tidak menunjukkan kesan yang signifikan. Dengan itu, didapati bahawa hasil kajian fungsi tindak balas teritlak adalah konsisten dengan ujian penyebab-Granger di mana inflasi cenderung sebagai pemboleh ubah kehadapan (leading) dan berupaya menjadi peramal (predictor) kepada kemeruapan inflasi di masa hadapan.

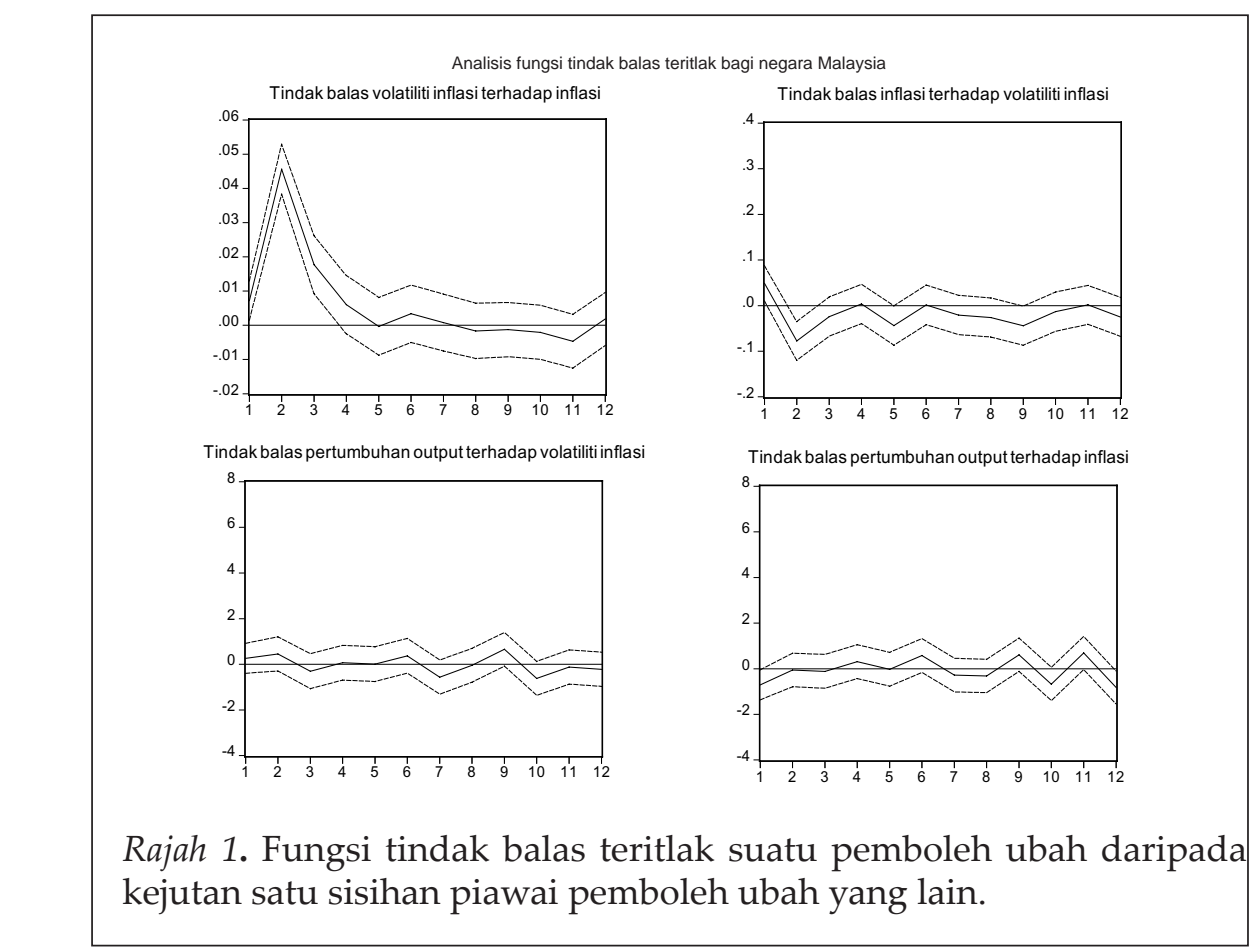

\section{KESIMPULAN}

Kajian ini bertujuan mengkaji hubungan dinamik antara inflasi, kemeruapan inflasi dan pertumbuhan output di negara Malaysia dari tahun 1980 hingga tahun 2004. Model EGARCH digunakan untuk menjana ukuran kemeruapan inflasi. Ujian penyebab-Granger seterusnya digunakan untuk mengkaji hubungan penyebab antara ketiga-tiga pemboleh ubah. Hasil kajian menggunakan model EGARCH menunjukkan bahawa wujud kesan asimetri di mana kejutan inflasi positif akan meningkatkan kemeruapan inflasi lebih banyak berbanding kejutan inflasi negatif. 
Hubungan antara inflasi dan kemeruapan inflasi di Malaysia adalah lebih menyokong hipotesis pertama Friedman dan hipotesis Holland. Di samping itu, analisis luar sampel menggunakan teknik dekomposisi varians dan fungsi tindak balas teritlak masing-masing menunjukkan keeksogenan pemboleh ubah inflasi dalam menerangkan kemeruapan inflasi dan kesannya adalah lebih signifikan berbanding dengan pemboleh ubah pertumbuhan output (diukur oleh pertumbuhan dalam IPI).

Secara keseluruhannya, didapati bahawa peningkatan dalam inflasi cenderung membawa kepada peningkatan dalam kemeruapan inflasi dan seterusnya mengurangkan pertumbuhan output di Malaysia. Manakala tempoh kemeruapan inflasi yang tinggi akan mengurangkan inflasi di mana keadaan inflasi di Malaysia adalah lebih bersifat motif penstabilan harga. Hal ini bermakna dasar monetari Malaysia adalah berasaskan penstabilan harga yang membawa kepada keadaan inflasi yang stabil. Dengan itu, kestabilan harga sepatutnya diberi tumpuan dalam perlaksanaan dasar ekonomi negara pada masa akan datang.

\section{RUJUKAN}

Ball, L. (1992). Why does inflation raise inflation uncertainty? Journal of Monetary Economics, 29, 371-388.

Barro, R. J. (1995). Inflation and economic growth. NBER Working Paper 5326.

Berument, H., \& Dincer, N. (2005). Inflation and inflation uncertainty in the G-7 countries. Physica A, 348, 371-379.

Berument, H., Metin-Ozcan, K., \& Neyapti, B. (2001). Modelling inflation uncertainty using EGARCH: An application to Turkey. Federal Reserve Bank of Louis Review, 66, 15-26.

Bollerslev, T. (1986). Generalized autoregressive conditional heteroscedasticity. Journal of Econometrics, 31, 307-27.

Cukierman, A., \& Meltzer, A. (1986). A theory of ambiguity, credibility, and inflation under discretion and asymmetric information. Econometrica, 54, 1099-1128.

Dickey, D., \& Fuller, W.A. 1979. Distribution of the estimates for autoregressive time series with a unit root. Journal of the American Statistical Association, 74, 427-431.

Engle, R.F. (1982). Autoregressive conditional heterokedasticity with estimates of the variance of UK inflation. Econometrica, 50, 9871007. 
Engle, R.F. (1983). Estimates of the variance of US inflation based upon the ARCH model. Journal of Money, Credit and Banking, 15, 286-301. Fernandez Valdovinos, C. (2001). Further evidence Friedman's hypothesis : The case of Paraguay. Cuadernos de economia, 38 N115.

Fountas, S., Ioannidis, A., \& Karanasos, M. (2004). Inflation, inflation uncertainty, and a common European monetary policy. Manchester School, 72, 221-242.

Fountas, S., Karanasos, M., \& Kim, J. (2003). Inflation uncertainty, ekonomi growth uncertainty, and macroeconomic performance. (Unpublished manuscript).

Fountas, S., Karanasos, M., \& Kim, J. (2002). Inflation and ekonomi growth uncertainty and their relationship with inflation and economic growth. Economics Letters, 75, 293-301.

-Fountas, S. (2000). The relationship between inflation and inflationuncertainty in the UK: 1885-1998. National University of Ireland Working Paper, No.48.

Fountas, S., Karanasos, M., \& Karanassou, M. (2000). A GARCH model D) of inflation and inflation uncertainty with simultaneous feedback. National University of Ireland Working Paper, No.47.

Friedman, M. (1977). Nobel lecture: Inflation and unemployment. Journal of Political Economy, 85, 451-472.

Golob, J.E. (1994). Does inflation uncertainty increase with inflation? Federal Reserve Bank of Kansas City. Economic Review, Third Quarter, 27-38.

Grier, K.B., \& Jerry, M.J. (2000). The effects of real and nominal uncertainty on inflation and ekonomic growth: Some GARCH-M evidence. Journal of Applied Econometrics, 15, 45-58.

Grier, K.B., \& Perry, M.J. (1998). On inflation and inflation uncertainty in the G7 countries. Journal of International Money and Finance, 17, 671-689.

Holland, S. (1995). Inflation and uncertainty: Tests for temporal ordering. Journal of Money, Credit, and Banking, 27, 827-837.

Jansen, D.W. (1999). Does inflation uncertainty affect ekonomi growth? Further evidence. Federal Reserve Bank of St. Louis Review, 71, 43-54.

Karanasos, M., Karanassou, M., \& Fountas, S. (2004). Analyzing US inflation by a GARCH model with simultaneous feedback, WSEAS Transactions on Information Science and Applications, 1, 767-772.

Kontonikas, A. (2004). Inflation and inflation uncertainty in the United Kingdom, evidence GARCH modeling. Economic Modelling, 21, 525-543.

Nas, T.F., \& Perry, M.J. (2000). Inflation, inflation uncertainty, and monetary policy in Turkey: 1960-1998. Contemporary Economy Policy, 18, 170-180. 
Nelson, D.B. (1991). Conditional heteroskedasticity in asset returns: A new approach. Econometrica, 59, 347-370.

Pagan, A. (1984). Econometric issues in the analysis of regressions with generated regressors. International Economic Review, 25, 221-247.

Pesaran, M. H., \& Y. Shin. (1998). Generalized Impulse Response Analysis in Linear Multivariate Models. Economics Letters, 58, 17-29.

Phillips, P., \& Perron, P. (1988). Testing for a unit root in time series regression. Biometrica, 75, 335-346. 


\section{APPENDIKS}
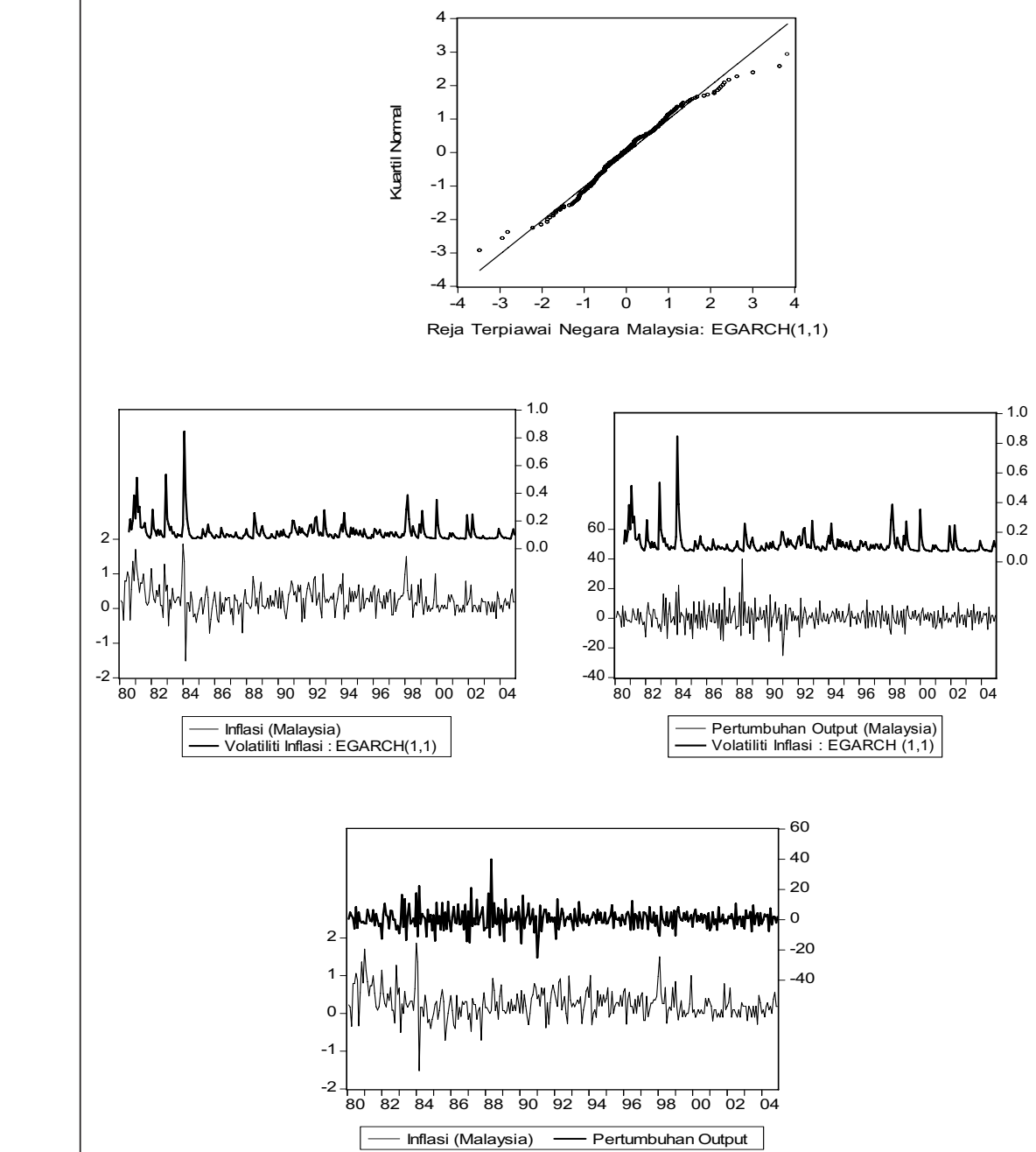

38 IJMS 16 (2), 21-38 (2009) 